\title{
ABUSE AND AUTHORITY IN THE CHESTER CYCLE: A SOCIALLY-BASED DISCOURSE
}

\author{
Begoña Crespo García \\ University of La Coruña
}

\begin{abstract}
The aim of this paper is to describe the relationship between the derogatory function of language - as the maximum lexical expression of the language of abuse and authority - and the social values of the late Middle Ages. To this end, the Chester Cycle, a speech-based body of work, has been analysed. Given that, as many authors state, the lexicon or vocabulary is the subsystem that best transmits the connection between language and society, I have selected lexical items and phrases representing oaths, insults and expletives for the purpose of my analysis. The semantic study of the items and sequences collected reveals that the social, religious, political, economic and cultural trends of the period are manifested through the use of abusive forms of address and other linguistic expressions of self-assertion.
\end{abstract}

\section{INTRODUCTION}

This paper examines how the language of abuse and authority as represented by insults, oaths and animal metaphors mirrors the socio-cultural values of medieval times. It is an attempt to study, from a sociological point of view, the language of the characters who participate in the different pageants of the Chester Cycle. To represent such thematic concerns formally, the paper will be divided as follows: section 1 will contain a description of the extra-linguistic background to drama in the late Middle Ages. Section 2 will outline a theoretical framework relating to the social nature of the language of abuse and authority itself. Section 3 will present the corpus of data, describing its compilation and will present a semantic analysis. Finally, in section $4 \mathrm{I}$ will propose my conclusions. 


\section{EXTRA-LINGUISTIC CONTEXT: THEATRE AND LIFE}

Local tradition mentions the Chester Cycle for the first time around 1368. The first written reference dates back to 1462, almost a century later. The last performance of the cycle took place in $1575 .{ }^{1}$ The values of the late Middle Ages, therefore, constitute the socio-cultural background to the performance of this dramatic piece. In this respect, two external circumstances have to be considered: the effects of medieval nationalism on the vernacular and the gradual secularisation of drama. Drama in the Middle Ages constitutes the collective medium for expressing the seminal principles of medieval thought ${ }^{2}$ in two opposite ways, either praising them or satirising them. Obviously, language is the vehicle of transmission. In drama, language use is aided by images in which prototypical characters reinforce the message contained in their discourse. The social significance of language is therefore double, in the sense that it manifests itself as representative of a particular character's behaviour but, also, as the maximum expression of medieval thought. The secular representation of the Christian liturgy is, in fact, the most striking social aim of the Mystery Cycles.

Since the fourteenth century there has been a general consensus regarding the presentation of religious principles through the performance of different Biblical episodes (both Old and New Testament). This has been done in a pedagogical manner in order to popularise intellectual concepts using the vernacular, that is to say, the language spoken by the illiterate who should be taught the doctrine of the Church. As Turville-Petre (1996: 27) states: "the fact that it [a text] was written in English rather than in Latin meant that it was open to a general readership". This was also one of Wycliffe's main aims, resorting to genres other than the dramatic. The language employed by the characters was a means of getting the audience involved in the actual performance and of communicating the social, cultural and religious conventions of the period. Despite the fact that

Drama was used as a part of the Church's liturgy and ritual from very early times, it would soon move outside the physical restraints of the church (...). Although remaining under the doctrinal control of the church, the new playwrights were able to develop their own interpretations of well-known scenes and characters. The increasing number of parts meant that it was no longer possible, as with the old liturgical drama, for all the actors to be clerics; laymen (and, in rare cases, laywomen) not only participated but, in larger towns and cities, took responsibility for the organisation and production (Higgins 1994: 11).

1. Kroll (2003: 338) even states that the Chester Shepherds' play was "most likely composed during the first quarter of the sixteenth century".

2. Based upon the theological and philosophical theories of authors such as St Augustine, St Thomas Aquinas or William of Ockham. 
This means that, though still serving the purposes of the Church, there is a progressive secularisation of drama that will be felt in the language used to convey didactic messages.

The late Middle Ages (14th $-15^{\text {th }}$ centuries) are a period of intense nationalist activity during which the vernacular tongue is defended as a standard of cultural identity (Crespo 1996). It is a period of gradual consolidation for the English language in most spheres of life (excluding the academic one). This is aided by interminable military confrontations (The Hundred Years' War against France), the activities engaged in by religious reformers such as Wycliffe and the Lollards, the literature written by Gower, Chaucer or Hoccleve, key socio-economic changes (the Black Death, the Peasants' Revolt), the expansion of the urbanisation process and various migratory movements and external factors which fostered the development of English to the detriment of any other foreign tongue. ${ }^{3}$

There is an identification between speech community and nation, which Turville-Petre (1996: 27) expresses in these terms: "author and audience became united in their nationality, and the clerical writer was able to appeal to the laity through a sense of nationhood, through a perception of shared social values, as in a commonly understood language". This reaffirmation of the vernacular can, for instance, be traced in the linguistic sequences of abuse and authority found in the texts. The actual linguistic usage together with the characters' interaction reveal social abuse and the use of authority, the social conventions and rules to be followed by speakers as members of a community in medieval life. Drama transforms common actions into theatrical performances (Kroll 2003).

Furthermore, this process brings about a change in the overall linguistic function of those dramatic pieces devoted to both education and entertainment. The didactic purpose is highlighted by the participation of non-religious people. The language of abuse and authority transmits both vernacular self-confidence and religious knowledge.

\section{PRELIMINARY CONSIDERATIONS ON THE LANGUAGE OF ABUSE AND AUTHORITY}

A study of the language of abuse and authority requires the consideration of two aspects: the communicative situation in which the characters interact and the corresponding linguistic code with special forms and functions. In the first case a

3. From the second half of the fifteenth century, the printing press also contributed to the expansion of the vernacular. 
speaker may play a relevant social role which endows her/him with authority and which may result in an abuse of that authority. The main power stakes are social status and/or role. Other factors such as age and sex may also play an important role. Moreover, speakers can make use of their linguistic code with different functions in a situation of this type: the imperative function (order, command), the persuasive function (threats, persuasion, obligation), the derogatory function (expletives, insults, vituperations) or the denominative function (vocatives and attention markers).

In the present study I am concerned with the derogatory function. Expletives, insults and other types of deprecatory items are used when a verbal exchange reaches its climax. This linguistic mechanism is an attempt to strengthen the social identity of the participants involved, i.e. the speaker and the listener/s. The speaker consolidates his/her authority by verbalising derisive terms or sequences. Likewise, this particular framework characterises and classifies the listener (Crespo 2003).

Some linguistic expressions denote authority through their use as insults, oaths and expletives ${ }^{4}$, strengthening the predominant system of values and revealing the socio-cultural background that lies behind language. They transmit information about a particular form of behaviour and linguistic code. All this demands a linguistic analysis of the characters' speech as members of a particular community. They are socially marked in accordance with medieval parameters. These characters enact biblical scenes using the different stylistic levels of the native tongue. The religious characters in the pageants embody prototypical human forms of behaviour which are common in everyday life, such as those related to abuse and authority. Some characters express authority in themselves, namely omnipotent figures such as God, Jesus and the angels. They occupy the top of the social pyramid in the medieval world. Consequently, their language is supposed to correspond to a high, aureate diction. Those placed at the bottom of the pyramid (shepherds, wives, the antichrist) employ colloquialisms and vulgar diction in general. Expletives, oaths and insults of any kind normally reveal the speaker's intention of reinforcing his/her personality in the conversation and his/her position as member of a community.

\section{METHODOLOGY AND ANALYSIS OF DATA}

For the purpose of this paper I have worked with the Early English Text Society Edition of the Chester Cycle first published by Lumiansky and Mills in 1974. All the plays, including the appendices, have been studied.

4. The chronological development of these forms (denotation-connotation axis) has been taken into account. 
It is the purpose of this analysis to assess how many different forms of either oaths or insults occur in the Chester Cycle and to look at the connection between this information and the external world. However, I shall not be concerned with the frequency of occurrence of each of these forms. It is not the object of this paper to determine their proliferation by means of an absolute quantification of repeated forms but to carry out a relative, qualitative study. These expressions originated from lexical items and, as is well known, the lexicon or vocabulary of a language is the subsystem by which the relationship between language and society may be best traced (Jihnzi 1992; Moskowich-Spiegel 1995; Romano Mozo 2001).

The forms found here have been classified as oaths, insults and other. Table 1 below shows the corresponding number of instances:

\begin{tabular}{|l|l|}
\hline Insults & 38 \\
\hline Oaths & 35 \\
\hline Other & 30 \\
\hline
\end{tabular}

Table 1. Number of different occurrences for each type.

Insults and oaths occur in almost the same number and can be interpreted as alternatives for manifesting contempt, authority and abuse. Other encompasses abstract lexical items which convey a similar meaning: power, treason and villainye are some examples.

Each type may have a greater either religious or secular referent. In what follows I will focus on insults and oaths.

\subsection{INSULTS}

The analysis of insults involves their semantic categorisation, as shown in table 2:

\begin{tabular}{|l|l|}
\hline Secular & Religious \\
\hline Sexual referent & Pagan referent \\
\hline Status referent & Moral referent $^{5}$ \\
\hline Intellectual referent & \\
\hline
\end{tabular}

Table 2. Semantic categorisation of insults.

5. The prevailing moral values were understood to be Christian. 
Most instances represent secular insults (25 forms). The general denomination secular may in turn be subdivided into insults of sexual, status and intellectual referent.

Terms of abuse with a clear reference to sexual promiscuity include whoore and stytton stallon. Whoore alludes to female sexuality and is used in the plays as in example 1 below:

(1) Balaak to Miles

Spare thou neyther ryche ne poore wyddowe, mayde, ne ylke whoore;

yf shee bee fresh of coloure,

bringe her with thee, I saye. (380-383) Moses and the Law; Balaack and Balaam; Balaam.

There seems to be a reference to the female sex in general. Balaak and Miles are representing members of the low classes. In this conversation Balaak makes use of a common way of classifying women, identifying, from a male perspective, the social roles they play, that is to say, widow, maiden or whore.

Stytton stallon makes reference to lascivious male conduct, represented by the metaphorical extension of "stallion". It is a term of abuse that denotes sexual promiscuity which, in turn, derives from the connotative association with the animal:

(2) Secundus Mulier to Secundus Miles

Saye, rotten hunter with thy gode,

stytton stallon, styck-tode.

I reade that thou no wronge us bode

lest thou beaton bee. (313-316) The Slaughter of the Innocents; Innocents.

The insult, as illustrated in example 2 above, uttered by a woman and addressed to someone belonging to the same social group, provokes a comic effect which helps to release the dramatic tension of a religious performance.

Insults referring to status, namely, begger, caytiffle, rybauld, harlott, quean, wretch (for wretch see example 6 below) share a common semantic feature, that of referring to low-born people. The fact of occupying a position at the base of the socio-economic hierarchy connects them with miserable, bad behaviour. The denotative meaning of status words is relegated to a less important position when those words are employed as contemptuous forms of address. This is what Lewis, in his 1960 publication Studies in words, called "the moralisation [and I would add "deterioration"] of status words". Examples (3) to (5) below illustrate this usage: 
(3) Cayne to Abell

Say, thou, caytiffe, thou congeon, weneste thou to passe mee of renowne?

Thou shalt fayle, by my crowne, of masterye yf I may. (601-604) Adam and Eve; Cain and Abel; Cain.

The denotative sense of caytiffe as "captive, prisoner" is the basis for its extension into "miserable or unfortunate person", that is to say, a poor man in both senses, of spirit and possessions. The fact that the character who embodies wickedness (Cayne) insults the character representing human goodness (Abell), is a symptom of irony and social devaluation.

(4) Antichristus

Rybaldes, rweled out of raye!

What ys the Trenyte to saye? (490-491) Manuscript P, the Peniarth "Antichrist".

In (4) the Antichristus uses rybaldes as an insulting word. It represents the standard of opposition to all rules of decorum. In fact, rybaldes is defined in the $M E D$ as

a) A person of low social status; a menial; king of ribaudes, = king of harlotes [see harlot n.4.(b)]; (b) a foot soldier; one of a band of irregular soldiers employed to ravage the countryside in advance of the army.

b) A wicked person; a scoundrel, villain, rascal; also, the devil; also, the name of a fiend; (b) a dissolute person, lewd person, debauchee, carouser, wastrel; also, a loose woman, harlot, strumpet; also, lechery personified [last quot.]; womman ; (c) a foul-mouthed person, scurrilous speaker; also, a jester, an entertainer; (d) as an abusive form of address.

All these meanings were current in late Middle English as illustrated in the MED through references to contemporary texts. This means that in the performance of the Chester Cycle it could easily be interpreted as an abusive form of address. Example (5) contains a further illustration:

(5) Prima Mulier to Primus Miles

Whom callest thou 'queane', scabde dogge?

Thy dame, thy daystard, was never syche.

Shee burned a kylne, eych stike;

yet did I never non. (297-300) The Slaughter of the Innocents; Innocents. 
The semantic evolution of queane in (5) can be described in two stages:

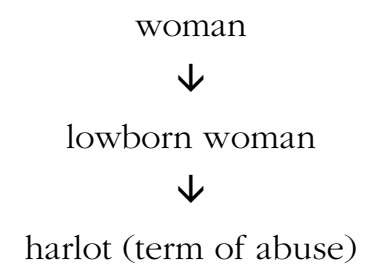

The first stage covers the general referent which is narrowed down to a specific kind of woman, characterised by her low social status. The next stage encompasses the deterioration of this status word. The MED definition offers further evidence of this: “(a) A woman; (b) a lowborn woman, quean; also, a harlot; also as term of abuse; (c) an old woman, a crone; (d) ? in place name".

The items pertaining to the intellectual referent group can be regarded as insulting, because they reveal a lack of intellectual capacity (fool, golys, goose, congeon -as in example 3 above-, madmen), the use of knowledge for evil purposes (wysard) or an extraordinary ability or development of one of the senses which can be regarded as jocular in a mocking situation (babelavaunt). This can be seen in examples (6) and (7):

(6) Antechristus

Oute on the, wysarde, with thy wylis,

for falsly my peple thowe begylus.

I shall the hastely honge,

and that lurdayn that stondys the bye- (371-374) Manuscript $P$, The Peniarth "Antichrist".

(7) Tertius Judeus to Cayphas

Syr Cayphas, herken nowe to mee!

This babelavaunt would our kinge bee,

whatsoever hee sayes nowe befor thee. (21-23) The Trial and Flagellation; Trial.

Treason and evil-doing are present in the Antichristus' discourse. Paradoxically, the reference to these religious topics contrasts once again with the character who mentions them. If in (6) wysard is used as an insulting word from a moral perspective, - "a person possessing great wisdom" who makes use of it to beguile-, in (7) humour is transmitted through the lexical item babelavaunt. It seems to be connected with bauble and baublery meaning "childish foolery or 
trifling business". Some obsolete expressions recorded in the OED point to the existence of combinations containing this item and meaning "to make a fool".

Still within "secular insults", golys, dogge, goose, lyon, bownd, lardan (see the spelling variant lurdayn in example 6 above) are some examples of what I have called animal metaphors, and could be interpreted as belonging to the intellectual type. There is an extension of metaphorical meaning by means of the additional feature [+ human]. The qualities or characteristics of the animal are just transferred to a human being. This transfer from [+ animal] to [+ human] implies a debasement, hence their use as terms of contempt:?

(8) Antechristus

Whrecchis! Golys! Ye ben blent.

Goddis Son I am, from hym sente.

Howe darr you maynten youre entente,

sithe he and I ben won? (513-516) Manuscript P, The Peniarth "Antichrist".

(9) Herodes

What the devell should this bee?

A boye, a growme of lowe degree,

shouId raygne above my ryalltee

and make me but a goose, (...) (201-204) The Three Kings; Magi.

These abusive terms are grounded in the perceptual, functional or emotional associations established by the speakers among the denotative characteristics of animals and what they simbolise. The individual perception of reality does not fit into fixed patterns but shifts according to the external world. This is certainly true of animal metaphors so intimately connected with culture (Stern 1931; LewandoskaTomasyck 1985; Crespo 1996; Nevalainen 1999; De la Cruz 2001). In this respect, references to animals, birds or beasts in the Chester Cycle merely mirror the sociocultural values of medieval times. Lions, for instance, symbolise nobility, power and, from a theological point of view, the sin of pride. A gull (example 8) is an immature or inexperienced bird; lack of experience is taken as a synonym for foolishness, stupidity. This is a quality assumed to be shared by geese also (example 9). Hence,

6. As a general Christian principle, animals were considered inferior to humans in terms of moral status. Linguistically, however, limited or improper intellectual activity among humans was identified with this baser animal nature.

7. This debasement as a consequence of a metaphorical extension can also be frequently traced in references to women. Insults such as basilisk, viper, carrion or bowlet are some examples. For more information see Crespo 1996. 
the interpretation of "simpleton" or "foolish person", when the term is applied to people. In broad terms, the significance of these metaphors could serve to assert an individual's values. In fact, though in an opprobrious sense, these insults reveal different manifestations of the human being. The goal of these metaphorical processes could entail a covert exaltation of the individual and his earthly dominance.

Some insults of a religious nature were also found (12 cases). A group of them contains obvious pagan references. They are mainly assigned to anti-Christian, antipapal, anti-Church of Rome practices: sinner, ragnayll, heretikes, bypocrites, beathen, lowlars are some examples, as illustrated in (10) and (11) below. They refer to Biblical episodes about the transgression of doctrinal values and represent prototypical groups that embody the distortion of the Christian faith. The use of these nouns as insulting words reveals the degree of integration of religious matters in the English medieval collective consciousness. In addition, entertainment is guaranteed by the reversal of all those values. It is a Judeus and the Antechristus who talk about heathens and lollards.

(10) Secundus Judeus

Thou shalt abye, by my bone,

or thou beathen passe.

Helpe, fellowe, and gather stones

And beate him well, for cockes bones. (255-258) The Blind Chelidonian; The Raising of Lazarus; The Blind Man.

The extra-linguistic reference is clearly seen in lowlars:

(11) Antechristus to Doctor

These lowlers, the would fayne me greeve

and nothinge one me the will leeve,

but ever be readye me to repreeve

and all the people of my lawe. (428-431) Antichrist.

In a time of turbulent movements and religious schisms, the name used to designate Wycliffe's followers, the main opponents of the postulates of the Church, is seen as a term of contempt and disparagement. The others are taken from biblical history. They represent the traditional disruption of God's word and law. Paganism was hitherto displayed through these insults. Opposition to paganism and to its sinful moral values was the trend of the period. This was the doctrine implicit in the didactic purpose of medieval drama and is linguistically manifested thus. 
Ragnayll in (12) below is used to embody metaphorically the evil behaviour of a human being. The term derives from the OF name of a Saracen king in Romance (MED). There is a link, therefore, between this insult and paganism. It constitutes another implicit religious reference by means of an abusive term.

(12) Antechristus

Ragnayll, thowe art my dere!

Nowe fare I wonder evull.

Alas, alas, were is my powere?

Alas, my wytt ys in a were. (651-654) Manuscript P, The Peniarth "Antichrist".

There is another group based on moral referents. It encompasses general terms of abuse with the semantic feature of treason and deceit lying behind the deprecatory tone with which they can be uttered. Since such behaviour is to be condemned by Christianity, these items exhibit a different degree of religious connotation: populard, traytour, scabde dogge (see example 5 above), thiefe, rotten bunter, fayture, tormentour, roysard. ${ }^{8}$ Examples (13) and (14) illustrate two of them in use and context:

8. Since populard is the only term discussed here, I include the MED definitions for the rest of the terms:

Traytour a) "One guilty of high treason against king (or ruler), realm, or people: (a) one who plots or accomplishes the death or disherison of the king or who conceals knowledge of such a plot; (b) one who kills or plots to kill a relative of the king or one of his magnates; (c) a violator of the king's wife or daughter; (d) one who aids the enemies of the king or the king's army or the foreign enemies of his country or city; a renegade; a deserter; also, one who hands over his king or city to an enemy by treachery; (e) a betrayer of royal or military secrets; a spy; (f) one who levies war against the king, a rebel; an insurrectionary, a revolutionary; $(\mathrm{g})$ a preacher of religious sedition, a traitor to the established order, a heretic; (h) one who commits an offense construable as high treason: a counterfeiter of the royal coinage; an accroacher of the king's power; a defier of the king's law; a thief of the king's goods; a corrupt magistrate; an insubordinate underling; also, more loosely, a criminal, an outlaw, a felon; also with diminished force as a term of mere abuse; as (a) , as if one were guilty of treason; (i) in proverbs and prov. Expressions.

b) (a) A sinner, an evildoer; to god, godes ; (b) a violator of the obligations of a divinely ordained office: an impious king; a wicked or negligent cleric; an unjust or church-robbing knight; etc.; also, an official persecutor of God's people; to (of) god (crist, treuth), godes ; (c) a sorcerer; prob. error for tregetour n".

Scabde (dogge): a dog "(a) Afflicted with scabies; suffering from some eruptive skin disease; scabby, mangy, etc.; (b) of the eyelids: suffering from redness, itching, inflammation, etc.; (c) inflamed; purulent, ulcerated; (d) having a scab; (e) fig. afflicted (with sin); (f) in terms of contempt: dirty; contemptible, wretched."

Thiefe: (a) One who steals, a thief, robber; also fig.; of preie; (b) one who robs by stealth, a sneak thief; also fig.; also, one who steals by cheating others; night $\sim$ [see also night n. 6. (d)]; (c) one who robs by force or the threat of force, a mugger; a brigand, bandit; also fig.; also, one who robs by breaking into a house; (d) a pirate; also, a slaver; of the se, se $\sim$; (e) a poacher; one who steals livestock; of bestes; (f) one who practices simony or usury; (g)one who withholds improperly what 
(13) Balaack to Balaham

Thow preachest, populard, as a pye:

the dyvell of hell thee destroye!

I bade thee curse my enimye;

therefore thow come mee to. (312-315) Moses and the Law; Balaack and

Balaam; Balaam.

(14) Pilatus

Fye, theeffe; fye, traytour,

fye on thee, thy truth ys full bare!

Fye, feynd; fye, feature;

hye hence. Fast I read that thou fare! (266-269) The Resurrection.

Populard, an originally Old French term, already quoted in the Old Testament, means "hypocrite" or "traitor" (MED). In this context it is applied to a character, Balaham, who is supposed to behave, speak and lie like a priest; hence, the restriction of meaning: "cursed priest". Religious criticism is implicit. Furthermore, the use of terms of opprobrium to convey the idea of treason in the religious sense of an evil deed manifests the disapproval of how the pervasive strong piety of medieval times is present in all spheres of life. Whereas Balaack mocks Balaam because of his similarity with a populard, Pilatus represents the religious and social authority that uses the same linguistic devices.

\subsection{OATHS}

Oaths constitute the framework under which the characters' self-confidence grows. The verbal force of these vulgarisms establishes the basis for a link between actors and audience; in broad terms, between theatre and life.

should be given to others as charity; one who appropriates for himself what is not properly his; one who takes something without need; also fig.; also, one who takes credit unjustly, a braggart [quot. c1450]; an accessory to a theft [quots. 1340, 1st \& 2nd]; felaue; (h) one of the two thieves crucified with Christ; (i) noiinge to a [misreading of $\mathrm{L}$ nocentes feri as nocentes furi].

Hunter: (a) A hunter; esp. one who hunts deer, boar, hare, etc.; also, a fowler; blast of hunteres, a group of hunters; (b) fig. a violent thief, robber; a devil; hunteres bende (bond), the Devil's snare; $\sim$ of men, an oppressor, a tyrant; (c) fish $\sim$, a fisherman; clothes, hunting garb; spere, a hunting spear; (d) in surnames and place names [see Smith PNElem. 1.270].

Fayture: A deceiver, imposter, cheat; esp., a beggar or vagabond who feigns injury or disease; false faitour; -often used as a term of abuse.

Tormentour: a) (a) A torturer; an officer charged with executing cruel punishments, esp. an executioner; also, a devil who tortures souls in hell; knight ; (b) ?a soldier; - prob. mistransl. of L tiro.

b) An oppressor, a persecutor; one who causes pain or distress; ?also, a betrayer or treacherous person [quot. a1425].

Roysard: A trickster, deceiver. 
Oaths can be classified as follows:

\begin{tabular}{|l|l|}
\hline Religious & Secular \\
\hline Good & Medieval code values \\
\hline Evil & Earthly/Ordinary referent \\
\hline
\end{tabular}

Table 3. Semantic categorisation of oaths.

In the Chester Cycle two kinds of oaths can be identified: of a secular or a religious nature (as in the case of insults), depending on the significance of the lexical structure that generates the oath. When two items are combined in a lexical structure at least one of them provides the audience with a clue as to whether the expression is of one type or the other (by God omnipotent).

In this mixture of fiction and reality it is religion that plays a relevant role and constitutes the main leit-motif for uttering oaths. In fact, most instances are of religious content (22). As Hughes (1991: 55) puts it:

An astounding volume of religious asseveration, ejaculation, blasphemy, anathema and cursing, both personal and institutional, fraudulent and genuine, poured forth in the course of the Middle Ages. The word of God, so signally absent from the older heroic asseverations, was used and abused, elevated, debased and distorted as never before. The sacred was made profane in a way which seems to us utterly paradoxical, particularly when one considers this debasement in relation to the major counter-trend of medieval literature, namely the elevation, glorification, indeed near deification of woman in the "Petrarchan" convention.

This is an attractive contrast for the audience who eventually demand to learn from novelties. The novelty may simply be the satisfaction of seeing the imposed canons turned upside down.

A further sub-classification within religious oaths is also possible if we take into account the main referent contained in the oath and the principle of Manicheism that lies behind medieval culture: Good vs Evil. Good includes expressions invoking God, Jesus, Christ, Saint John or the fathers as in by God omnipotent, for Jesus sake, by Christe, by sayncte John or by my fathers kynn, as in (15) to (17) below:

(15) Noes Wiffe to Noe

By Christe, not or I see more neede,

though thou stand all daye and stare. (103-104) Noah's Flood. 
(16) Noes Wyffe

But I have my gossips everyechone,

one foote further I will not gone.

They shall not drowne, by sayncte John,

and I may save there life. (201-204) Noab's Flood.

(17) Secundus Judeus

By my fathers kynn,

noe parte hasse thou therin;

but, or I hethen wynne,

this coate shalbe myne. (125-128) The Passion.

Oaths uttered by a woman, as in the case of Noah's wife, intensify the mocking treatment of the female sex and their lack of authority. However, as was mentioned before for insults, these oaths confirm the deep religiosity of society in general since it was uncommon for women to belong to the literate elite in the Middle Ages.

There are even explicit references to faith or grace and concepts of religious spirituality, as can be seen in (18) and (19):

(18) Tertius Pastor

By my fayth, hee was some spye,

our sheepe for to steale.

Or elles hee was a man of our crafte,

for seemely hee was and [wounder] defte. (394-397) The Shepherds.

(19) Petrus

Be thou so bould, as thrive I,

to hould my maister here in hye,

full deare thou shalt hit abye

but thou thee heathen dight.

Thy eare shall of, by Goddes grace,

or thou passe from this place. (327-332) The Last Supper; the Betrayal of Christ; Betrayal.

Some "minced forms" (Hughes 1991: 66) of the type for cockes soule, for cockes blood, for cockes face, in which the word cockes represents an euphemistic variant of God, may also be included here:

(20) Herodes to Jesus

Speake on, Jesu, for cockes blood, 
for Pilate shall not, by my hood, do the non amys; but mend thy mood and speake somwhat with mee. (183-186) The Trial and Flagel-lation.

Between these two forms of expressing blasphemy and profanity, a gradually increasing degree of irreverence can be traced. Especially irreverent are those expressions that mention parts of the body: for cockes blood, face, although the use of the euphemism minimises the religious impact of these "intimate references to the person and sufferings of Christ" (Hughes 1991: 56).

Evil occupies the other end of the scale with demotic expressions such as what the divell, what devill of hell, the devylles owne or in twentye devylles waye. Opposition to the dogmas of Christianity also flourishes in oaths that allude to paganism and other religions: the existence of heathens, pagans and allusions to Mohammed, by Mabound, by saynct Mabound:

(21) Herodes to Secunda Mulier Alas, what the divell is this to meane?

Alas, my dayes binne now donne!

I wott I must dye soone. (417-419) The Slaughter of the Innocents.

(22) Noe $^{9}$ to Noes Wyffe

Come in, wife, in twentye devylles waye,

or ells stand there withowte. (219-220) Noab's Flood.

(23) Secundus Miles to Herode

But for to kyll such a conjoyne

mee shames sore, by saynct Mabound,

to goe in any place. (166-168) The Slaughter of the Innocents.

Example (23) is another instance of the ironic treatment of paganism: Mohammed is paradoxically classified as saynct, so sacred a matter for the Christian faith. It juxtaposes two opposite creeds in an imprecation, a linguistic device which expresses ironically the principles that rule over the external world.

Instances of secular oaths are less numerous (13). They can also be considered as representative of the medieval code of values. Thus, for a knight or anyone intending to ascend the social ladder, the defence of honour, honesty and truth was

9. The good or evil referent of an oath does not depend on the character's nature (good-bad) but on the circumstances of its expression. It is a pragmatic aspect that has not been studied in this paper. 
of paramount importance. Consider, for example, (24) to (26), in which the aforesaid values are mentioned:

(24) Primus Pastor to Secundus Pastor

Fye, man, for shame!

Call him Tudd, Tybbys sonne,

and then wyll the shrewe come; (...) (64-66) The Shepherds.

(25) Tertius Judeus

And here are, by my pon,

nayles good wonne

to nayle him upon

and he were my brother. (157-160) The Passion.

(26) Cayne to Deus

And yf I lenge, by my lewtye,

I muste bee bonde and nothinge free -

And all for my follye. (638-640) Adam and Eve; Cain and Abel; Cain.

Shame implies disapproval of ignominious conduct or loss of esteem ${ }^{10}$ whereas the two remaining lexical items, namely, pon and lewtye, ${ }^{11}$ denote decency, rectitude, justice, honourableness, compromise.

Apart from this group of secular abstract qualities of high social consideration, other more earthly or common matters can be traced in oaths:

(27) Secundus Judeus to Jesus

Thou shalt abye, by my bone,

or thou heathen passe.

Helpe, fellowe, and gather stones

and beate him well, for cockes bones. (255-258) The Blind Chelidonian;

the Raising of Lazarus; The Blind Man.

10. I have included here what could be considered a religious oath to illustrate the degree of importance of religion in the medieval code of values, though shame is an abstract concept and should not be placed at the level of Christ in by Christe or God in by God omnipotent.

11. Both terms are defined in the $M E D$ as follows:

Pon: ? Security, ? keeping.

Lewtye: (a) Uprightness, honorableness, honesty; truth; justice, fairness; in , uprightly, justly; don $\sim$, to do justice, deal uprightly; (b) loyalty, faithfulness; (c) allegiance; holden , to stick to one's allegiance, act in accordance with an oath of allegiance; kepen $\sim$ with, owe allegiance to (sb.); sweren , swear allegiance (to sb.); (d) loyalty or uprightness personified; (e) bi mi $\sim$, on my honor; upon my word, certainly; bi thi (oure, your, his) , for thi (your) ; (f) in (god) , truly, certainly; (g) ? as adj.: loyal, true; (h) as surname. 
(28) Herodes to Jesus

Speake on, Jesu, for cockes blood, for Pilate shall not, by my hood,

do the non amys; but mend thy mood

and speake somewhat with mee. (183-186) The Trial and Flagellation.

(29) Cayne to Abell

Thou shalt fayle, by my crowne,

Of masterye yf I may. (601-602) Adam and Eve; Cain and Abel; Cain.

The combination of religious and secular oaths in drama reveals the interaction of religious and secular matters in the socio-external reality. Examples (29) and (30) illustrate this alternate use in a character's discourse. At any rate, in by my bone, it is a Jew who reproduces those allusions to Christ's anatomy that were examined before. It is just the corresponding profane version. The imitation of religious patterns may also help to explain the nature of by my bood and by my crowne. Both hood and crown can be regarded as metonymical expansions of bead, representing the two opposite poles of the social pyramid: upper (crown) versus low (hood).

\section{CONCLUSIONS}

The language of abuse and authority has been studied in this paper in terms of the use of the derogatory function as a means of expressing the social background to the late Middle Ages. In this sense, the linguistic analysis has been restricted to insults, oaths and some animal metaphors. Insulting and swearing are the two main verbal actions by the speaker to exert abuse and authority. The meaning of these expressions reveals the tendencies and the characteristics of the external world -with either a physical or a philosophical presentation- as has been shown earlier in the explanation of some of them.

The analysis of the forms used in the derogatory function of language reveals that the number of insults and oaths is approximately the same. Their first subcategorisation, secular vs. religious, sets up an opposition between them: insults are mainly secular, while religious oaths predominate over secular ones. This confirms what Hughes, in his 1991 book entitled Swearing, stated although he did not enter deeply into the analysis of secular insults. However, as has been shown here, some of these secular insults cannot be regarded as strictly secular but merely as transpositions of religious expressions. Oaths -exclamatory and authoritative in 
tone-, which are uttered to reinforce the speaker and intimidate the listener, seem to be more firmly grounded in religiosity than insults.

Moreover, apart from this initial sub-categorisation, there is an assorted range of referents based on sex, status, intellectual ability, the lay medieval canon, Manicheism and earthly matters, which contributes to further categorisations.

In summary, the study of the derogatory function of language through insults, oaths and animal metaphors (not included as a separate section but analysed within the first group), with all the taxonomies that can be established, provides us with a valuable source of socio-historical and cultural reference, most notably in relation to the level of integration of moral doctrines, social differences and an incipient tendency to secularise everyday life in the burlesque treatment of serious matters.

\section{REFERENCES}

Ashley, K. M. 1978. "Divine Power in the Chester Cycle and Late Medieval Thought". Journal of the History of Ideas, 39: 387-404.

Axton, R. 1974. European Drama of the Early Middle Ages. London: Hutchinson University Library.

Cawley, A. C. et al., eds. 1983. The Revels History of Drama in English. Vol. 1. London \& New York: Methuen.

Clopper, L. M. 1980. "Tyrants and Villains. Characterization in the Passion Sequences of the English Cycle Plays". Modern Language Quarterly 41: 3-20.

Craik, T. W. 1973. "Violence in the English Miracle Plays". Medieval Drama. Ed. D. Neville. London: Edward Arnold. 173-195.

Crespo, B. 1996. "Women and Sex in the Elizabethan Period: A World through Language". Proceedings of the XIXth International Conference of AEDEAN. Eds. J. Pérez Guerra, M. T. Caneda Cabrera, M. Dahlgren, M. T. FernándezColmeiro, and E. J. Varela Bravo. Vigo: Universidade de Vigo, Servicio de Publicacións. 217-221.

-. 2003. "The Language of Abuse and Authority in Volpone or the Fox". Babel Afial 12: 105-123.

Crespo, B., and C. Mourón. 1997. "Theatre, Humour and Women: A "Mishmash" full of Life". European Medieval Drama. Ed. S. Higgins. Camerino: Universitá degli Studi di Camerino. 393-421.

De la Cruz Cabanillas, I. and F. J. Martín Arista, eds. 2001. Lingüística histórica inglesa. Barcelona: Ariel.

Harty, J., ed. 2000. The Chester Mystery Cycle: A Casebook. New York: Garland. 
Higgins, S. 1994. Medieval Theatre in the Round. Camerino: Universitá degli Studi di Camerino.

Hilton, R. 1985. Class Conflict and the Crisis of Feudalism. London: The Hambledon Press.

Hughes, G. 1991. Swearing. A social History of Foul Language, Oaths and Profanity in English. Oxford: Blackwell.

Jinhzi, S. 1992. "Culture and language change: from the perspective of two groups of words". Journal of Macrolinguistics 2: 105-109.

Kroll, N. 2003. "The Towneley and Chester Plays of the Shepherds: The Dynamic Interweaving of Power, Conflict, and Destiny". Studies in Philology 100/3: 315345.

Kurath, H. et al. 1959. 2003. 06.28. Middle English Dictionary. Middle English Dictionary website. http://ets.umdl.umich.edu/m/med/

Lewandowska-Tomaszczyk, B. 1985. "On Semantic change in a dynamic model of language". Historical Semantics, Historical Word-formation. Ed. J. Fisiak. Berlin/ New York: Mouton de Gruyter. 297-323.

Lewis, S.C. 1960. Studies in Words. Cambridge, UK: Cambridge University Press.

Lumiansky, R. M., and D. Mills, eds. 1974/1986. The Chester Mystery Cycle. Vols. I/II. Oxford: OUP, The Early English Text Society.

MacLean, S-B. 1982. Chester Art: a Subject List of Extant and Lost Art Including Items Relevant to Early Drama. Kalamazoo, Mich.: Medieval Institute Publications, Western Michigan University.

May, S. 1983. "Good Kings and Tyrants: A Re-assessment of the Regal Figure on the Medieval Stage". Medieval English Theatre 5/2: 87-102.

Mills, D. 1983. "Characterisation in the English Mystery Cycles: A Critical Prologue". Medieval English Theatre 5/1: 5-17.

-. 1994. "The Chester Cycle". The Cambridge Companion to Medieval English Theatre. Ed. R. Beadle. Cambridge, UK: Cambridge University Press.

Moskowich-Spiegel Fandiño, I. 1995. Los escandinavos en Inglaterra y el cambio léxico en inglés medieval. A Coruña: UDC. Servicio de Publicacións.

Murray, J. A. H. et al. 1994 [1933]. The Oxford English Dictionary. Oxford: OUP. (CD-ROM 2nd edition).

Nevalainen, T. 1999. "Early Modern English Lexis and Semantics". The Cambridge History of the English Language. Volume III. 1476-1776. Ed. R. Lass. Cambridge, UK: Cambridge University Press. 332-458.

Romano Mozo, M. 2001. "El léxico medieval inglés: características y evolución". Lingüística histórica inglesa. Ed. I. De la Cruz Cabanillas, and F. J. Martín Arista. Barcelona: Ariel. 378-404. 
Stern, G. 1931. Meaning and Change of Meaning, with Special Reference to the English Language. Göteborg: Elanders Boktryckeri Aktiebolag.

Turville-Petre, T. 1996. England the nation: language, literature and national identity, 1290-1340. Oxford: Clarendon Press. 